\title{
DOUBLE/JOINT DEGREE PROGRAM DEVELOPMENT: STAGES AND ACADEMIC LEADERSHIP
}

\author{
Olena Humenna \\ Postgraduate Student, Institute of Higher Education of National Academy \\ of Educational Sciences, Ukraine \\ e-mail: olena_humenna@ukr.net,orcid.org/0000-0003-3644-8758
}

\section{Summary}

The article presents the legislative basis for double/joint degree programs development in Ukraine. The stages for developing double/joint degree programs used in the European Higher Education Area (EHEA) have been described.

The Academic Council of the university / faculty approves the working (project) group, the head of which is the guarantor of the educational program. The procedure for developing, reviewing and approving educational programs, compliance with the principles and procedures of quality assurance (monitoring, evaluation, internal accreditation, periodic review, and termination procedure) are determined by separate provisions in universities.

Keywords: educational program, internationalization, the European Higher Education Area (EHEA), assessment stage, development stage, evaluation stage, management stage, termination stage.

DOI https://doi.org/10.23856/4107

\section{Introduction}

The modern period for the policy of international education modernization began in 2014, when the Association Agreement between Ukraine and the European Union was signed. Within the framework of the regular reform of higher education, the law of Ukraine "On Higher Education" (adopted in the same year) identifies the key principles (Article 75) for creating joint educational programs as one of the main areas for international cooperation (Zakon Ukrainy "Pro vyshchu osvitu”, 2014).

At a conference of Ministers of education in France (May 2018), it was noted that most countries made changes to the legislative instruments contributing to joint programs, but some uncertainty remaining due to a lack of clear legislative framework was also emphasized (Bologna Process Implementation Report, 2018: 276).

The purpose of this paper is to identify the stages of double/joint degree program development and determine the role of academic leadership for double/joint degree program development.

\section{Legislative basis for double/joint degree program development in Ukraine}

The state policy of Ukraine in the field of higher education is based on the higher education system integration into the European Higher Education Area (EHEA) and the European Research Area (ERA). Integration into the EHEA and the ERA was identified to be the second priority area for reforming higher education system during 2018-2019 (Hrynevych, 2017).

The implementation of this direction means the higher education internationalization, which is one of the leading tendencies in the development of higher education in the world. 
Internationalization in higher education is defined as "the process of integrating the educational, research and administrative activities of a higher education institution or institution of higher education or a scientific institution with an international component: individual mobility (students, scholars, teachers, administrative staff); creation of joint international educational and research programs" (Natsionalnyi osvitnii hlosarii: 25).

In order to become a priority, the question "why internationalization?" must receive quite realistic and sufficiently pragmatic answers in the national strategy. While the challenge for improving the quality of higher education in line with world and European standards through the development and implementation of new international educational programs and integration into the curricula of international elements and educational standards is much more realistic and directly urgent. The same can be said about integration into the EHEA through the purposeful expansion of programs of international cooperation and partnership at the individual and institutional levels, the creation of strategic educational alliances.

The National Qualifications Framework (Natsionalna ramka Ukrainy), the List of Areas of Knowledge and Specialties for Higher Education Applicants (Pro zatverdzhennia pereliku haluzei znan i spetsialnostei), the Regulations on the Procedure for Exercising the Right to Academic Mobility (Polozhennia pro poriadok realizatsii prava na akademichnu mobilnist), the ratified Convention on the Recognition of Qualifications concerning Higher Education in the European Region (Pro ratyfikatsiiu Konventsii) form the legal basis for development and implementation of joint educational programs in the Ukrainian higher education institutions.

The National Qualifications Framework is a systematic and competency-based description of qualification levels of education. Each level is a completed stage of education, characterized by the level of complexity of the educational program, a set of individual competencies, which are usually defined by the standard of education and meet a certain level. The updated National Qualifications Framework harmonizes it with the European standards and creates conditions to facilitate the mutual recognition of qualifications, ensures the comparability of educational and professional qualifications that people acquire in Ukraine with qualifications obtained abroad. Thus, having received educational or professional qualifications abroad, a person can easily confirm them here and get a job without any problems.

On the other hand, in the face of fierce competition in response to the demands of transformational change in society and the contemporary needs of students, universities are constantly developing their own development strategies, reflecting in their regulatory framework, in particular, the strategy of implementing joint programs. But not every Ukrainian university currently offers such programs to students.

International cooperation/activities in universities are regulated by the following documents: University Charter, Regulations on the organization of the educational process, Regulations on the procedure for exercising the right to academic mobility etc.

A detailed analysis of national strategies for internationalization of higher education in the countries of the world and the identification of peculiarities and tendencies of internationalization development has been done by M. Debych in her study "Internationalization of higher education: world experience", in which the author emphasizes that internationalization of Ukrainian higher education has not become a priority" (Debych, 217: 248). One of the positive effects of internationalization on the education system as a whole, the scientist considers the importance of recognizing joint degrees (Debych, 217: 257). 


\section{Double/joint degree program development}

The National Glossary defines "Educational program" as a system of educational components at the appropriate level of higher education within the specialty, which determines the requirements for the level of education of persons who can start studying under this program, the list of disciplines and their logical sequence for study, the number of ECTS credits required for the implementation of this program, as well as the expected learning outcomes (competences), which must be mastered by the applicant for the appropriate degree of higher education" (Natsionalnyi osvitnii hlosarii: 42-43)

According to the Tuning methodology, the process of developing an educational program includes the following stages (Zakharchenko et al., 2014: 27)

1. "Verification of compliance with the basic conditions (public need, consultations with stakeholders, academic novelty of the program, whether common points of reference, resources inside/outside the higher education institution (scientific institution) have been identified).

2. Defining the profile of the educational program.

3. Description of the purpose of the program and the final learning outcomes.

4. Definition of general and professional competences.

5. Curriculum development.

6. Development of modules and selection of teaching methods.

7. Defining approaches to learning and assessment methods.

8. Development of a system for evaluating the quality of the educational program in order to improve it".

According to the recommendations of the European Association of Universities, 10 golden rules for programs that end with the award of joint degrees are (European University Association: 23-24): 1) motivation; 2) careful choice of partner; 3) clear goals of the program and its results; 4) institutional support of the program; 5) sufficient potential of academic and administrative staff to implement the program; 6) financial support of the program; 7) easily accessible information about the program; 8) a sufficient number of meetings with partners for the development and implementation of the program; 9) the issue of the language of instruction has been resolved; 10) clearly defined and distributed responsibilities among the partners.

The European directory identifies the following stages for development of the educational program (Guide: 22).

At the assessment stage it is necessary to: determine the motivation for cooperation; choose the right partners; provide academic and administrative support; schedule meetings to discuss challenges; share responsibilities; provide financial resources; develop the programs; discuss recruitment issues.

At the development stage it is necessary to: draw up and sign a Memorandum of Understanding; make sure that partner higher education institutions are accredited; hold meetings to discuss challenges; apply for financial support (if available); develop a curriculum / program description; develop criteria and procedures for admission, appeal procedures, obtaining a diploma; provide information about the program, conduct marketing and recruitment; discuss the support of students upon arrival; approve the curriculum in all partner institutions; develop and sign a cooperation agreement.

At the evaluation stage it is carried out: evaluation and quality assurance of the program (courses); internal reporting of institutions and reporting of the consortium; external evaluation of the program; transaction verification; making decisions on the continuation or termination of cooperation. 
At the management stage it is done: admission and enrollment; arrival and settlement; decision-making on the Diploma and the Diploma Supplement; information provision and marketing; quality assurance.

At the termination stage of the program it is necessary to: ensure predictability and responsibility to students; enable students to complete their studies successfully.

\section{Academic leadership in the double/joint degree program development}

Academic leadership is the name given to leadership in an academic setting or organization as a special subdivision of overall leadership. Academic leadership is a leadership that includes such roles as creating vision and mission based on science and research data for the organization, setting up creative ideas, doing and providing teamwork (What is academic leadership?).

According to T. Kennie there are six dimensions of academic leadership: credibility; curiosity; collegiality; capabilities; character; confidence (Kennie, 2010). Each dimension has its domains. For example, credibility needs to be demonstrated and earned in four domains: personal (academic achievements), peer (positive support from the academic community), positional (building the reputation of the wider academic unit) and political (dealing with the inevitable political challenges which arise in higher education) (Kennie, 2010).

Having analyzed the process of double/joint degree program development in the Ukrainian universities represented in QS World University Rankings (2019) V.N. Karazin Kharkiv National University (Kharkivskyi natsionalnyi universytet imeni V.N. Karazina), Taras Shevchenko National University of Kyiv (Kyivskyi natsionalnyi universytet imeni Tarasa Shevchenka), National Technical University Ukraine Polytechnic Institute named after Ihor Sikorskyi ("Kyivskyi politekhnichnyi instytut im. Ihopia Sikorskoho"), National Technical University "Kharkiv Polytechnic Institute" (Natsionalnyi tekhnichnyi universytet "Kharkivskyi politekhnichnyi instytut”), Sumy State University (Sumskyi derzhavnyi universytet), National University of Lviv ("Lvivska politekhnika") we have come to a conclusion.

The Academic Council of the university / faculty approves the working (project) group, the head of which is the guarantor of the educational program. The procedure for developing, reviewing and approving educational programs, compliance with the principles and procedures of quality assurance (monitoring, evaluation, internal accreditation, periodic review, and termination procedure) are determined by separate provisions in universities.

Thus, in Ukrainian universities academic leadership has not been introduced into practice.

\section{Conclusions}

Internationalization has significant modernizing potential and, at the same time, poses a significant challenge to the national higher education system and universities as its main structural element. On the one hand, these are new prospects for their development, and, on the other hand, they are new forms of competition both in the global educational field and in the European Higher Education Area.

Ukraine has a legislative basis for double/joint degree program development at the national and institutional levels.

However, the double/joint degree program development is strictly regulated by the university administration and academic leadership has not been introduced into practice. 


\section{References}

Debych, M.A. (2017). Internatsionalizatsiia vyshchoi osvity: svitovyi dosvid [Internationalization of higher education: world experience] : monohrafiia. Sumy: Universytetska knyha. [in Ukrainian].

Developing Joint Master's Programmes for Europe (2004). Results of the EUA Joint Masters Project (March 2002-Jan 2004). European University Association. Brussels, Belgium. Retrieved from http://www.eua.beleua/jsp/en/upload/Joint_Masters_report.1087219975578. pd. [in English].

European Commission/EACEA/Eurydice (2018). The European Higher Education Area in 2018: Bologna Process Implementation Report. Luxembourg: Publications Office of the European Union. Retrieved from https://eacea.ec.europa.eu/national-policies/eurydice/sites/eurydice/files/bologna_internet_chapter_7_0.pdf. [in English].

Guide to developing and running joint programmes at bachelor and master's level. A template. Retrieved from https://www.joiman.eu/ProjectResults/PublicDeliverables/JOIMAN\%20 template_JP final.pdf. [in English].

Hrynevych, $\vec{L}$. Prioritetni napriamy zmin u vyshchii osviti na 2018-2019 roky [Priority directions for changes in higher education for 2018-2019]. Retrieved from https://mon.gov.ua/storagelapp/media/vishcha-osvita/infographik/MON_prioritety_new.pdf. [in Ukrainian].

Kennie, T. (2010). Academic leadership: Dimensions and dynamics. Engage: Issue 21. P. 10-11. URL: Retrieved from http://www.bristol.ac.uk/media-library/sites/staffdevelopment/documents/AcademicLeadership_Dimension\&Dynamics.pdf. [in English].

Kharkivskyi natsionalnyi universytet imeni V.N. Karazina. Pro upravlinnia. Retrieved from https://www.facebook.com/int.relations.karazin. [in Ukrainian].

Kyivskyi natsionalnyi universytet imeni Tarasa Shevchenka. Retrieved from http://www.univ. kiev.ua/ua/official. [in Ukrainian].

Natsionalna ramka Ukrainy [National Framework of Ukraine] : Dodatok do postanovy Kabinetu Ministriv Ukrainy vid 23 kvitnia 2011 r. № 1341. Retrieved from https://zakon.rada.gov. ua/laws/show/1341-2011-\%D0\%BF/paran12\#n12. [in Ukrainian].

Natsionalnyi tekhnichnyi universytet "Kharkivskyi politekhnichnyi instytut”. Retrieved from https://www.kpi.kharkov.ua/ukr/mizhnarodni-zv-yazki/viddil-mizhnarodnih-zv-yazkiv/. [in Ukrainian].

Natsionalnyi technichnyi universytet Ukrainy "Kyivskyi politekhnichnyi instytut im. Ihopia Sikorskoho”. Retrieved from https://www.education.ua/ua/universities/106/. [in Ukrainian].

Natsionalnyi universytet "Lvivska politekhnika". Retrieved from https://lpnu.ua/international. [in Ukrainian].

Paryzke komunike [Paris Communique] (2018). Retrieved from http:/lerasmusplus.org.ual images/phocadownload/PARIS_COMMUNIQU_En_UA_2018_web.pdf. [in Ukrainian].

Pro ratyfikatsiiu Konventsii pro vyznannia kvalifikatsii z vyshchoi osvity v Yevropeiskomu rehioni [On ratification of the Convention on the Recognition of Qualifications concerning Higher Education in the European Region]. Lisabon, 11 kvitnia 1997 roku. Retrieved from https://zakon.rada.gov.ua/laws/show/994_308\#Text. [in Ukrainian].

Pro zatverdzhennia pereliku haluzei znan i spetsialnostei, za yakymy zdiisniuietsia pidhotovka zdobyvachiv vyshchoi osvity [On the statement of the list of branches of knowledge and specialties on which preparation of applicants of higher education is carried out] (2015) : Postanova Kabinetu Ministriv vid 29 kvitnia 2015 r. № 266. Retrieved from https://www.kmu.gov.ua/ npas/248149695. [in Ukrainian]. 
Pro zatverdzhennia Polozhennia pro poriadok realizatsii prava na akademichnu mobilnist [Regulations on the procedure for exercising the right to academic mobility] (2015) : Postanova Kabinetu Ministriv vid 12 serpnia 2015 p. № 579. Retrieved from https://zakon.rada.gov. ua/laws/show/579-2015-\%D0\%BF\#Text. [in Ukrainian].

Sumskyi derzhavnyi universytet. Retrieved from https://www.sumdu.edu.ua/uk/international. html. [in Ukrainian].

What is academic leadership? Retrieved from https://www.igi-global.com/dictionary/academic-leadership/58173. [in English].

Zakharchenko, V.M., Kalashnikova, S.A., Luhovyi, V.I. et al. Natsionalnyi osvitnii hlosarii: vyshcha osvita [National Educational Glossary; Higher Education] (2014) / za zah. red. V.H. Kremenia. MON Ukrainy, NAES Ukrainy, Nats. Tempus-office v Ukraini. 2-he vyd., pererob. i dop. Kyiv: Pleiady. [in Ukrainian].

Zakharchenko, V.M., Luhovyi, V.I., Rashkevych, Yu.M., Talanova, Zh.V. (2014). Rozroblennia osvitnikh prohram [Educational program development] : metodycnni rekomendatsii / za red. V.H. Kremenia. Kyiv: DP "NVTs "Priorytety". [in Ukrainian].

Zakon Ukrainy "Pro vyshchu osvitu” vid 01.07.14. № 1556-VII [Law of Ukraine "On Higher Education” from 01.07.14. № 1556-VII]. Hazeta "Holos Ukrainy” vid 06.08.14 № 148. [in Ukrainian]. 